\title{
Effect of Thermal Annealing on the $\mathrm{Cd}(\mathrm{OH})_{2}$ and Preparation of $\mathrm{Cdo}$ Nanocrystals
}

Nadana Shanmugam*, Balan Saravanan, Rajaram Reagan, Natesan Kannadasan, Kannadasan Sathishkumar and Shanmugam Cholan Department of Physics, Annamalai University, Annamalai Nagar, Chidambaram 608 002, Tamilnadu, India

\begin{abstract}
Nanosized $\beta-\mathrm{Cd}(\mathrm{OH})_{2}$, were successfully synthesized via simple chemical precipitation method using cadmium nitrate as a precursor in a solution of sodium hydroxide. The $\mathrm{CdO}$ nanoparticles were harvested from $\beta-\mathrm{Cd}(\mathrm{OH})_{2}$ by thermal decomposition at $400^{\circ} \mathrm{C}$. The structural, optical, and magnetic properties of the as prepared and annealed products of $\beta-\mathrm{Cd}(\mathrm{OH})_{2}$, were studied. The morphology of the $\mathrm{CdO}$ nanocrystals annealed at $400^{\circ} \mathrm{C}$ analyzed by $\mathrm{FE}-$ TEM exhibits pseudo spherical morphology with sizes around $60 \mathrm{~nm}$.
\end{abstract}

Keywords: Nanosized $\beta-\mathrm{Cd}(\mathrm{OH})_{2}$; Decomposition; Annealed products; Magnetic properties

\section{Introduction}

In the past two decades, new terms with prefix nano have captured ample space among the scientific community owing to the unusual physical and chemical properties of nanomaterials. Usually on the basis of size, morphology and structure applications of nanomaterials are justified. Recently, interests in the study of Transparent Conductive Oxide (TCO) nanomaterials have gained special attention due to their important applications in the current technology. Among the transparent conducting metal oxide semiconductor materials, $\mathrm{CdO}$ is an important $\mathrm{n}$-type semiconductor material with direct band gap of 2.2-2.7 eV and indirect band gap of 1.36-1.98 eV [1]. CdO finds its potential applications in the field optoelectronics devices such as solar cells, phototransistors, photodiodes, transparent electrodes, catalysts and gas sensors [2-11]. Despite cadmium is toxic, $\mathrm{CdO}$ is widely used as a photo catalyst for effluent treatment $[4,12,13]$. Many researchers have reported the preparation of $\mathrm{CdO}$ nanostructures with different methods such as chemical vapour deposition, sol-gel, laser ablation, spray pyrolysis and hydrothermal methods. Nowadays, the usage of the simple chemical precipitation method in comparison with other methods increases among researchers because of its less time consuming and less expensive nature. Lotf Ali, et al. have synthesized $\mathrm{Cd}(\mathrm{OH})_{2}$ and $\mathrm{CdO}$ nanocrystals by the solvothermal method. They predicted the conversion of nanosized $\mathrm{Cd}(\mathrm{OH})_{2}$ into $\mathrm{CdO}$ at $500^{\circ} \mathrm{C}$ [14]. Siraj et al. have studied the magnetic properties of Al-doped CdO thin films and reported their para and ferromagnetic behaviors [15].

Herein, we demonstrate a simple chemical precipitation method for the synthesis of nanocrystalline $\beta-\mathrm{Cd}(\mathrm{OH})_{2}$. Nanocrystals of $\mathrm{CdO}$ can be obtained through the thermal decomposition using the asprepared $\beta-\mathrm{Cd}(\mathrm{OH})_{2}$ as precursor.

\section{Materials and Methods}

\section{Chemicals}

Cadmium nitrate hexahydrate $\left[\mathrm{Cd}\left(\mathrm{NO}_{3}\right)_{2}^{*} 6 \mathrm{H}_{2} \mathrm{O}\right]$, sodium hydroxide $[\mathrm{NaOH}]$ were purchased from Merck and were used as received since they were of analytical reagent grade with $99 \%$ purity. Ultra-pure water was used for all procedures of sample preparation and dilution.

\section{Synthesis of CdO nanocrystals}

In the preparation of $\mathrm{CdO}$ nanocrystals from cadmium nitrate hexahydrate $\left(\mathrm{Cd}\left(\mathrm{NO}_{3}\right)_{2}{ }^{*} 6 \mathrm{H}_{2} \mathrm{O}\right)$ and sodium hydroxide $(\mathrm{NaOH}), 0.5$
$\mathrm{M}$ of $\mathrm{Cd}\left(\mathrm{NO}_{3}\right)_{2}{ }^{*} 6 \mathrm{H}_{2} \mathrm{O}$ in $50 \mathrm{ml}$ of deionized water and $2 \mathrm{M}$ of $\mathrm{NaOH}$ in $50 \mathrm{ml}$ water were mixed up dropwise. The entire mixture was stirred magnetically until a white precipitate of cadmium hydroxide hexahydrate was formed. The resultant precipitate was filtered and then washed alternately with deionized water and ethanol for 3 times to remove the impurities. Further, the precipitate of cadmium hydroxide hexahydrate $\left(\mathrm{Cd}(\mathrm{OH})_{2}^{*} 6 \mathrm{H}_{2} \mathrm{O}\right)$ was dried in hot air oven at $100^{\circ} \mathrm{C}$ for 4 $\mathrm{h}$ and cadmium hydroxide was harvested in the nanosize. The obtained product was thermally annealed at different temperatures $(200,300$, 400,600 and $800^{\circ} \mathrm{C}$ ) for $2 \mathrm{~h}$. The formation of $\mathrm{CdO}$ took place at $400^{\circ} \mathrm{C}$ upon thermal annealing.

\section{Growth mechanism}

Formation of $\mathrm{Cd}(\mathrm{OH})_{2}$, in the presence of $\mathrm{NaOH}$ can be explained on the basis of buffer action of cadmium ions. Cadmium ions in the solution become hydrated and transformed to solid cadmium hydroxide through stepwise coordination of hydroxyl ions. However, depending upon the concentration of the base and the synthesis temperature, cadmium hydroxide is transformed into cadmium oxide through dehydration.

\section{Apparatus}

The prepared products were characterized by powder X-Ray Diffraction (XRD) on a X'PERT PRO diffractometer with $\mathrm{Cu}-\mathrm{Ka}$ radiation ( $k=1.5406 \AA$ ). From the line broadening, the size of the particle was estimated by the Scherrer equation. FT-IR analysis was made to characterize the functional groups of the precursor and nanosized cadmium oxide using SHIMADZU-8400 with a resolution of $4 \mathrm{~cm}^{-1}$. The Photoluminescence (PL) emission spectra of the samples were recorded with a Spectroflurometer (Jobin Yvon, FLUOROLOGFL3-11). Vibrating Sample Magnetometer (VSM) is used to identify the nature of magnetic species in the material. To study the morphology and size of the nanocrystals FE-TEM (Model JSM 2100F JEOL, Japan) analysis was made.

*Corresponding author: Nadana Shanmugam, Department of Physics, Annamalai University, Annamalai Nagar, Chidambaram 608 002, Tamilnadu, India, Tel: +91-944-427-6357; E-mail: quantumgosh@rediffmail.com

Received March 17, 2013; Accepted May 21, 2014; Published May 26, 2014

Citation: Shanmugam N, Saravanan B, Reagan R, Kannadasan N, Sathishkumar $\mathrm{K}$, et al. (2014) Effect of Thermal Annealing on the $\mathrm{Cd}(\mathrm{OH})_{2}$ and Preparation of Cdo Nanocrystals. Mod Chem appl 2: 124. doi:10.4172/2329-6798.1000124

Copyright: $(2014$ Shanmugam N, et al. This is an open-access article distributed under the terms of the Creative Commons Attribution License, which permits unrestricted use, distribution, and reproduction in any medium, provided the original author and source are credited. 


\section{Results and Discussion}

\section{Thermal analysis}

To understand the thermal behavior of $\beta-\mathrm{Cd}(\mathrm{OH})_{2}$, TG-DTA analyses were carried out between room temperature and $1000^{\circ} \mathrm{C}$ with a heating rate of $20^{\circ} \mathrm{C} / \mathrm{min}$ in nitrogen atmosphere. Figure 1 shows the TG and DTA traces of $\beta-\mathrm{Cd}(\mathrm{OH})_{2 .}$. Five prominent weight losses were observed at the end set temperatures $157^{\circ} \mathrm{C}(2.63 \%), 244^{\circ} \mathrm{C}(9.61 \%)$, $398^{\circ} \mathrm{C}(2.79 \%), 729^{\circ} \mathrm{C}(2.58 \%)$, and $1000^{\circ} \mathrm{C}(11.39)$. The initial weight loss of $2.63 \%$ observed between room temperature and $157^{\circ} \mathrm{C}$ could be ascribed to the removal of water molecules adsorbed on the surface of the $\mathrm{Cd}(\mathrm{OH})_{2}$ nanoparticles. The dehydration process involved in the first stage is given by the following chemical equation

$$
\mathrm{Cd}(\mathrm{OH})_{2}{ }^{*} \mathrm{X}_{\mathrm{ads}} \mathrm{H}_{2} \mathrm{O} \rightarrow \mathrm{Cd}(\mathrm{OH})_{2}+\mathrm{X} \mathrm{H}_{2} \mathrm{O}
$$

From the initial weight loss of $2.63 \%$, it is possible for us to estimate the amount of water exists in the as prepared $\mathrm{Cd}(\mathrm{OH})_{2}$. From the weight loss, the water absorption in molar fraction has been calculated as $0.0215 \mathrm{M}$ (moles of $\mathrm{H}_{2} \mathrm{O}$ per mole of $\mathrm{Cd}(\mathrm{OH})_{2}$ ). Therefore, the possible dehydration reaction is modified as

$$
\mathrm{Cd}(\mathrm{OH})_{2}{ }_{2}^{*} 0.0215 \mathrm{M} \mathrm{H}_{2} \mathrm{O} \rightarrow \mathrm{Cd}(\mathrm{OH})_{2}+0.0215 \mathrm{M} \mathrm{H}_{2} \mathrm{O}
$$

The second stage of weight loss occurring between $157-244^{\circ} \mathrm{C}$ may be ascribed to the transformation of $\beta-\mathrm{Cd}(\mathrm{OH})_{2}$ into $\gamma-\mathrm{Cd}(\mathrm{OH})_{2}$. The third stage of weight loss predicted between $244-398^{\circ} \mathrm{C}$ is due to the decomposition of $\gamma-\mathrm{Cd}(\mathrm{OH})_{2}$ into $\mathrm{CdO}$. The fourth stage of minimum weight loss of $2.58 \%$ recorded between $398-729^{\circ} \mathrm{C}$ indicating the improved crystallinity of the $\mathrm{CdO}$. A final and fifth stage of steep weight loss of $11.39 \%$ ascribed to the transformation of CdO nanocrystals into $\mathrm{CdO}_{2}$. The DTA curve of $\beta-\mathrm{Cd}(\mathrm{OH})_{2}$, shows two endothermic peaks at $204^{\circ} \mathrm{C}$ and $354^{\circ} \mathrm{C}$ corresponding to the removal of adsorbed water and decomposition of $\mathrm{Cd}(\mathrm{OH})_{2}$ into $\mathrm{CdO}$ respectively. Further, the DTA curve exhibits two exothermic peaks at $272^{\circ} \mathrm{C}$ and $695^{\circ} \mathrm{C}$ which are related to the phase transformation of $\mathrm{Cd}(\mathrm{OH})_{2}$ and conversion of $\mathrm{CdO}$ into $\mathrm{CdO}_{2}$ respectively. The obtained DTA results support the results of the TG curve.

\section{XRD analysis}

The XRD patterns of as-synthesized and annealed products are shown in Figure 2. As synthesized products exhibited twelve

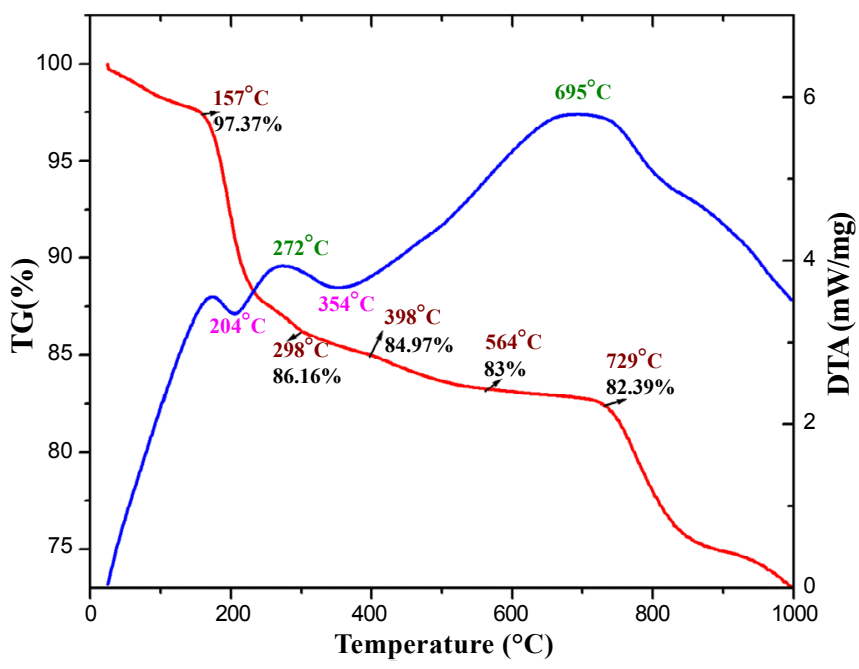

Figure 1: TG-DTA Curves of nanosized $\mathrm{Cd}(\mathrm{OH})_{2}$.

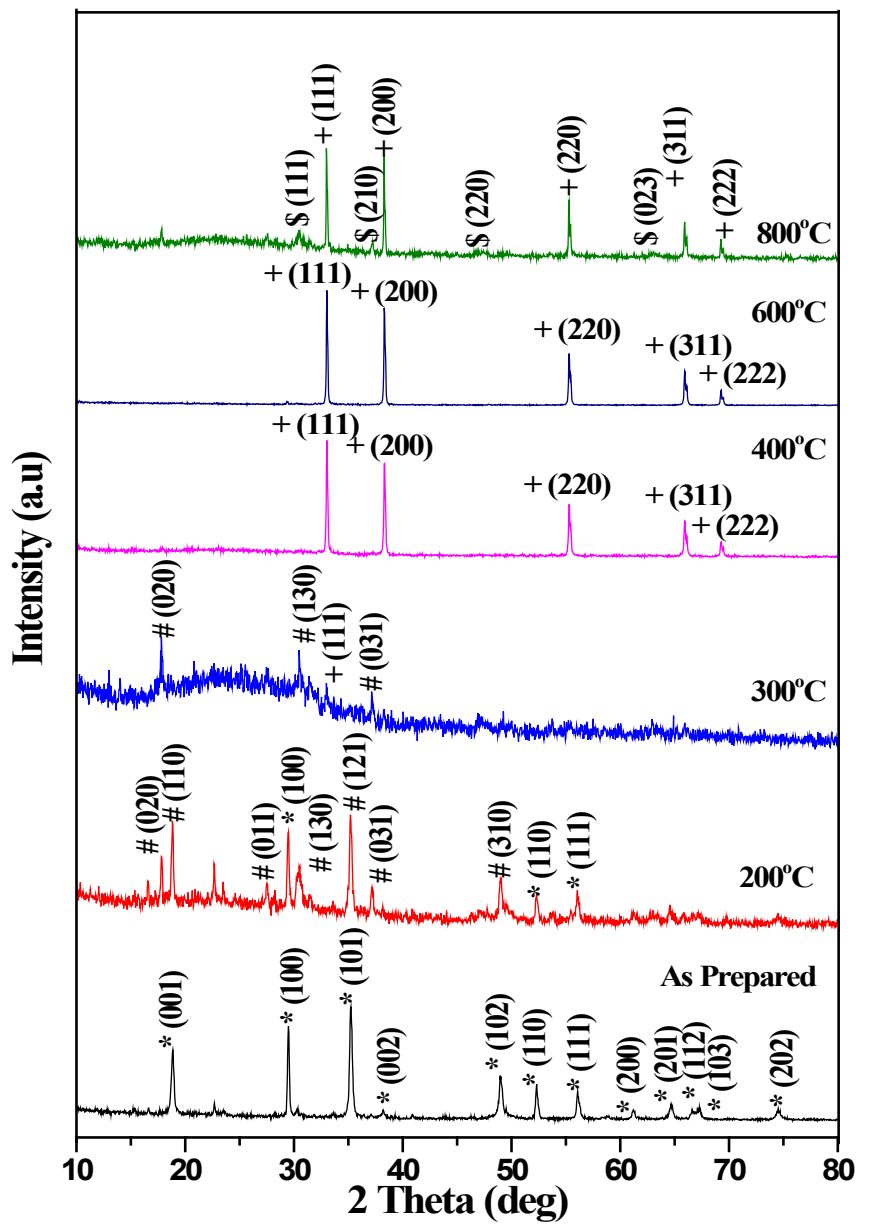

Figure 2: XRD patterns of as prepared and annealed $\mathrm{CdO}$ nanocrystals ( $\mathrm{Cd}(\mathrm{OH})_{2}$-Hexogonal; \# Cd(OH$)_{2}-$ Monoclinic; + CdO-Cubic; $\$ \mathrm{CdO}_{2}-$ Cubic).

diffraction peaks corresponding to the (001), (100), (101), (002), (102), (110), (111), (200), (201), (112), (103) and (202) planes of hexagonal $\beta-\mathrm{Cd}(\mathrm{OH})_{2}$ nanoparticles. The XRD patterns of the products annealed at $200^{\circ} \mathrm{C}$ show the presence of hexagonal as well as monoclinic (JCPDS: 20-0179) phases of $\gamma-\mathrm{Cd}(\mathrm{OH})_{2}$. Further, on annealing at $300^{\circ} \mathrm{C}$, in addition to the (020), (130) and (031) planes of monoclinic phase of $\gamma-\mathrm{Cd}(\mathrm{OH})_{2}$, a dominating cubic (111) peak of $\mathrm{CdO}$ is also seen. After annealing at high temperatures of 400 and $600^{\circ} \mathrm{C}$, the diffraction peaks could be indexed as (111), (200), (220), (311) and (222) planes of cubic CdO (JCPDS: 05-0640). The XRD patterns of the sample annealed at $400^{\circ} \mathrm{C}$ show the formation of pure cubic phase of CdO. However, the sample annealed at $600^{\circ} \mathrm{C}$ shows sharp diffraction peaks with reduced peak width as a result of improved crystallinity. Further annealing of the sample at $800^{\circ} \mathrm{C}$ leads to the formation of both cubic $\mathrm{CdO}$ and $\mathrm{CdO}_{2}$.

The average grain size was calculated from the XRD patterns using the Debye Scherrer's formula [16] for the as prepared and annealed products. The crystal structure, lattice parameters, and particle size of the as prepared and annealed products are given in Table 1. As can be seen from the table, the grain size increases with annealing temperature and thus the crystallization of the products is improved. The lattice constants calculated for all the products almost identical to the JCPDS values, especially the lattice parameters of the products annealed after 400 and $600^{\circ} \mathrm{C}$ exactly match the JCPDS values. 
Citation: Shanmugam N, Saravanan B, Reagan R, Kannadasan N, Sathishkumar K, et al. (2014) Effect of Thermal Annealing on the Cd(OH) 2 and Preparation of Cdo Nanocrystals. Mod Chem appl 2: 124. doi:10.4172/2329-6798.1000124

Page 3 of 5

\section{FT-IR analysis}

FT-IR analysis was used to study the $\beta-\mathrm{Cd}(\mathrm{OH})_{2}$ powder during heating. The heated samples were ground with $\mathrm{KBr}$ and pressed into pellets. IR spectra were recorded on samples after heat treatment at $200,300,400,600$ and $800^{\circ} \mathrm{C}$. As shown in Figure 3 the IR spectra of the as-prepared sample annealed at $100^{\circ} \mathrm{C}$ show a sharp and intense band at $3605 \mathrm{~cm}^{-1}$ arising from the stretching vibrations of structural $\mathrm{OH}$ groups confirming they are $\beta-\mathrm{Cd}(\mathrm{OH})_{2}[11,17]$. Usually $\beta-\mathrm{Cd}(\mathrm{OH})_{2}$ can show a band at around $3605 \mathrm{~cm}^{-1}$, whereas $\gamma-\mathrm{Cd}(\mathrm{OH})_{2}$ may provide absorption bands at around 3588 and $3531 \mathrm{~cm}^{-1}$. Absorption bands observed around 3447 and $1640 \mathrm{~cm}^{-1}$ are respectively assigned to the stretching and bending vibrations of $\mathrm{H}_{2} \mathrm{O}$ molecules. Further, on heating at $200^{\circ} \mathrm{C}$, the sharpness of the band at $3603 \mathrm{~cm}^{-1}$ decreases and a new band at $3522 \mathrm{~cm}^{-1}$ emerges. This indicates the conversion of $\beta-\mathrm{Cd}(\mathrm{OH})_{2}$ into $\gamma-\mathrm{Cd}(\mathrm{OH})_{2}$. Upon heating at $300^{\circ} \mathrm{C}$, the absorption band at $3603 \mathrm{~cm}^{-1}$ completely disappeared. Since the absorption bands of $\gamma-\mathrm{Cd}(\mathrm{OH})_{2}$ are predicted at 3524 and $3584 \mathrm{~cm}^{-1}$, the observation

\begin{tabular}{|c|c|c|c|c|c|}
\hline \multirow{2}{*}{$\begin{array}{c}\text { Temperature } \\
\left({ }^{\circ} \mathrm{C}\right)\end{array}$} & \multirow[t]{2}{*}{ Product } & \multirow{2}{*}{$\begin{array}{l}\text { Crystal } \\
\text { structure }\end{array}$} & \multicolumn{2}{|c|}{ Lattice parameters $(\AA)$} & \multirow{2}{*}{$\begin{array}{c}\text { Particle } \\
\text { size } \\
\text { (nm) }\end{array}$} \\
\hline & & & $\begin{array}{l}\text { Slandered } \\
\text { values }\end{array}$ & $\begin{array}{l}\text { Calculated } \\
\text { values }\end{array}$ & \\
\hline 100 & $\mathrm{Cd}(\mathrm{OH})_{2}$ & Hexagonal & \multirow[t]{2}{*}{$\begin{array}{l}a=3.494 \\
c=4.710\end{array}$} & $\begin{array}{c}a=3.4973 \\
c=4.791\end{array}$ & 41.29 \\
\hline \multirow[t]{2}{*}{200} & $\mathrm{Cd}(\mathrm{OH})_{2}$ & Hexagonal & & $\begin{array}{l}a=3.5002 \\
c=4.8132\end{array}$ & 38.96 \\
\hline & $\mathrm{Cd}(\mathrm{OH})_{2}$ & Monoclinic & \multirow[t]{2}{*}{$\begin{array}{c}a=5.63 \\
b=10.18 \\
c=3.4127\end{array}$} & $\begin{array}{l}a=5.0231 \\
b=9.9507 \\
c=3.4127\end{array}$ & 34.52 \\
\hline \multirow[t]{2}{*}{300} & $\mathrm{Cd}(\mathrm{OH})_{2}$ & Monoclinic & & $\begin{array}{l}a=5.0131 \\
b=9.9317 \\
c=3.4012\end{array}$ & 99.82 \\
\hline & $\mathrm{CdO}$ & Cubic & \multirow[t]{3}{*}{$a=4.695$} & 4.7004 & 19.15 \\
\hline 400 & $\mathrm{CdO}$ & Cubic & & 4.6963 & 64.63 \\
\hline 600 & $\mathrm{CdO}$ & Cubic & & 4.6960 & 86.46 \\
\hline \multirow[t]{2}{*}{800} & $\mathrm{CdO}$ & Cubic & $a=4.695$ & 4.6984 & 98.61 \\
\hline & $\mathrm{CdO}_{2}$ & Cubic & $a=5.313$ & 5.0789 & 17.20 \\
\hline
\end{tabular}

Table 1: Crystal structure, lattice parameters, and particle size of the as prepared and annealed products.

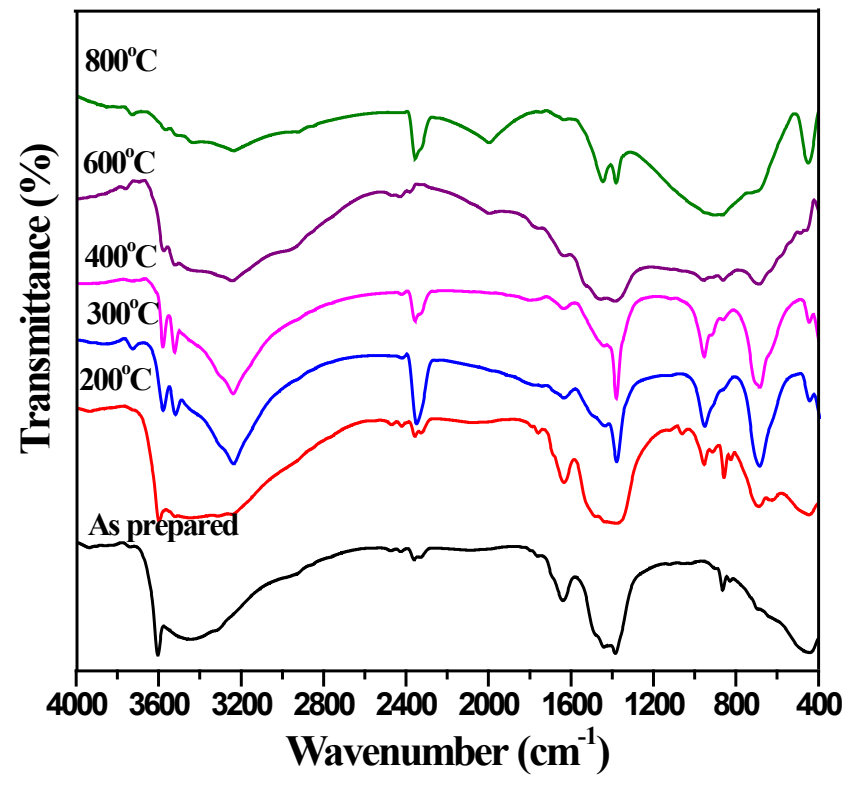

Figure 3: FT-IR spectra of as prepared and annealed CdO nanocrystals.

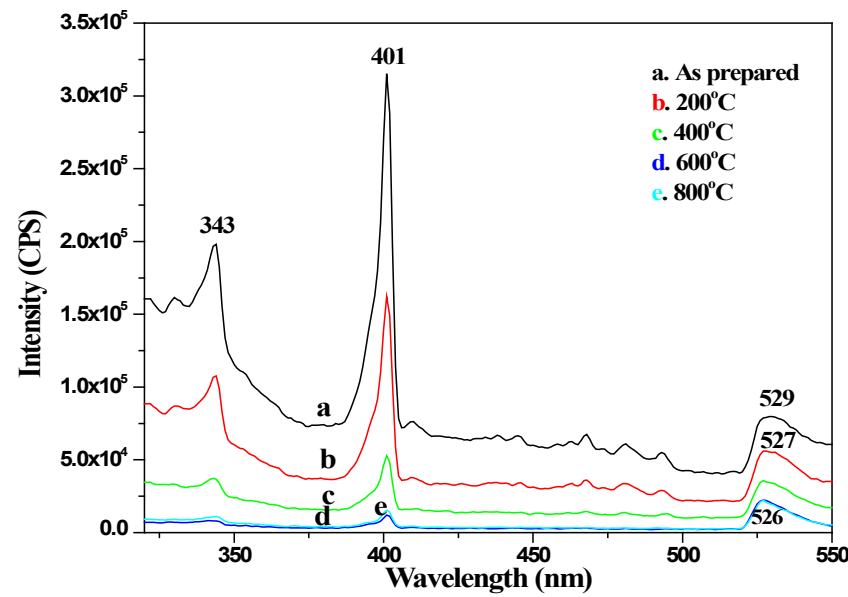

Figure 4: PL emission spectra of as prepared and annealed $\mathrm{CdO}$ nanocrystals.

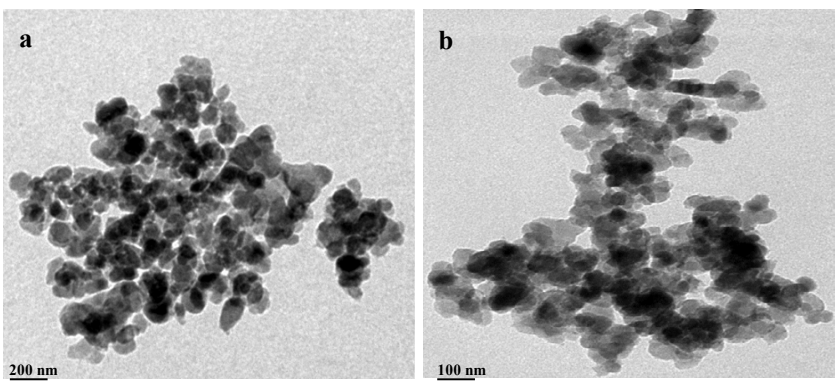

Figure 5: FE-TEM micrographs of $\mathrm{CdO}$ nanocrystals annealed at $400^{\circ} \mathrm{C}$.

confirms a complete transformation from $\beta-\mathrm{Cd}(\mathrm{OH})_{2}$ to $\gamma-\mathrm{Cd}(\mathrm{OH})_{2}$ [18]. According to the literature, the bands in between $800-1400 \mathrm{~cm}^{-1}$ belong to the Cd-O vibration [19]. In addition, peaks around 685 and $447 \mathrm{~cm}^{-1}$ could be ascribed to the Cd-O stretching mode [14]. After being at $400^{\circ} \mathrm{C}$, the formation of $\mathrm{CdO}$ is characterized by the sharp bands positioned at 1383, 686 and $447 \mathrm{~cm}^{-1}$. On further annealing $(600$ and $800^{\circ} \mathrm{C}$ ) the characteristic peaks of $\mathrm{Cd}-\mathrm{O}$ are broadened as a result of increased particle size.

\section{Photoluminescence}

The room temperature Photoluminescence (PL) spectra of as prepared and annealed products with $250 \mathrm{~nm}$ excitation are shown in Figure 4. All the products show three emission peaks positioned at 343 , 401 and $527 \mathrm{~nm}$. The peak appearing at 343 and $401 \mathrm{~nm}$ are assigned to the near band edge emission of $\mathrm{CdO}$ originating from excitonic transitions between the electrons in the conduction bands and the holes in the valence bands. The emission peak at $527 \mathrm{~nm}$ may be ascribed to structural defects such as vacancies and surface traps [20,21]. With such visible emission, the $\mathrm{CdO}$ nanocrystals can be utilized in the industry of high-quality monochromatic laser.

As a general behavior, the PL spectra of the $\mathrm{CdO}$ nanomaterials showed a relatively broad less intense UV and visible emission bands as the annealing temperature is raised. This is due to the fact that the oxygen vacancy concentration decreases after annealing at high temperatures. However, the position of the emission bands are not majorly changed as the annealing temperature is raised from 200$800^{\circ} \mathrm{C}$. This suggests that these emission bands are weakly associated with the band gap properties. 

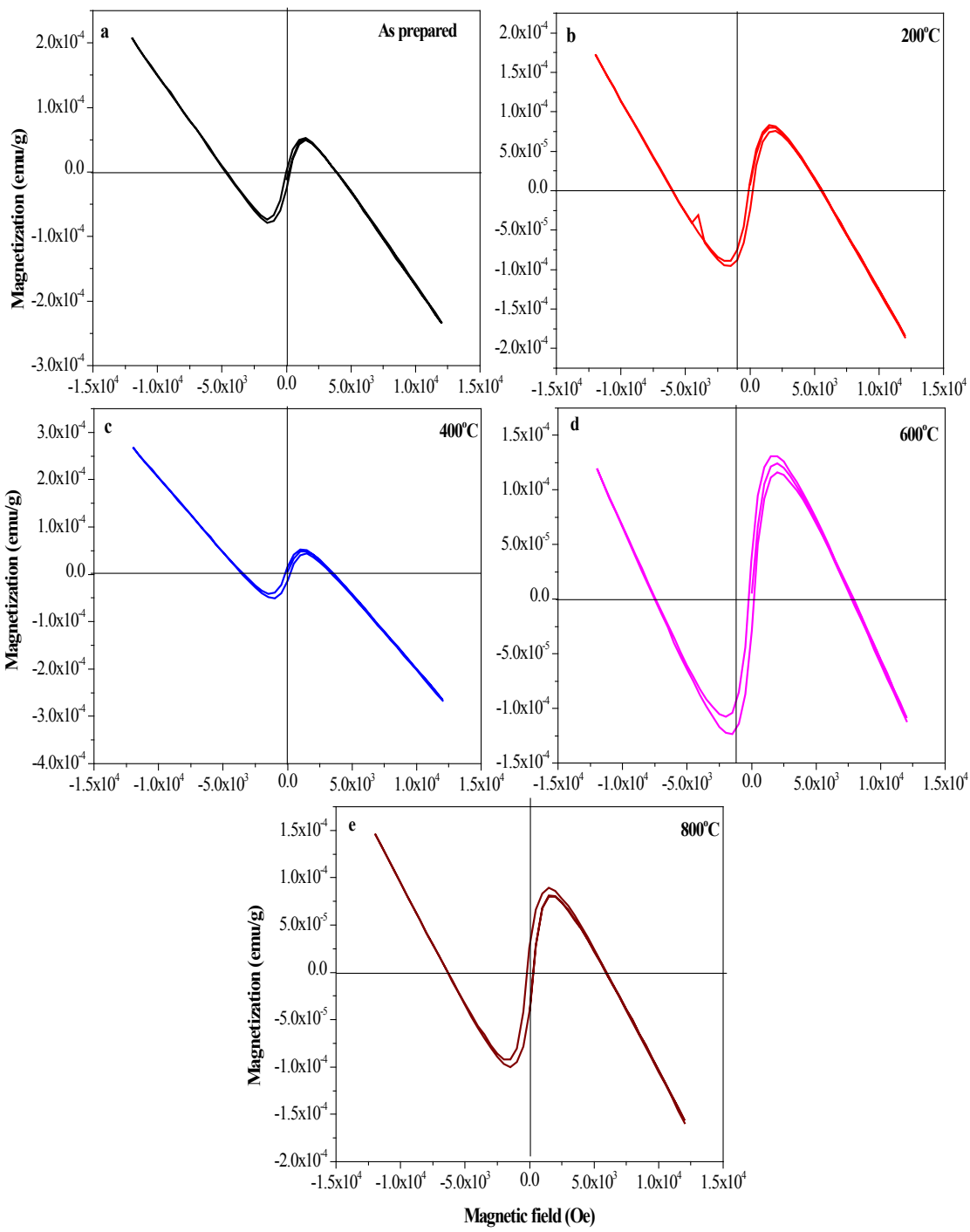

Figure 6: M-H loops of as prepared and annealed CdO nanocrystals.

\section{Field emission-transmitting electron microscope analysis}

FE-TEM analysis was used to evaluate the shape and size of the $\mathrm{CdO}$ nanoparticles. FE-TEM micrographs of $\mathrm{CdO}$ annealed at $400^{\circ} \mathrm{C}$ are shown in Figure $5 \mathrm{a}$ and $\mathrm{b}$. The annealed sample is constituted of pseudo spherical $60 \mathrm{~nm}$ sized particles. The entire observed particles have almost same diameter. The value of crystallite size obtained from the FE-TEM analysis is in good agreement with the value obtained from the Scherrer's formula.

\section{Magnetic characterization}

The magnetic behavior of $\mathrm{CdO}$ nanoparticles has not been much investigated so far. Vibrating sample magnetometer was used to study the magnetic properties of $\mathrm{CdO}$ nanocrystals at different growth temperatures. Figure 6 a-e shows the hysteresis loops for as prepared and annealed $\mathrm{CdO}$ nanocrystals. It can be observed that both as-prepared and annealed formulations reveal typical paramagnetic behavior. The paramagnetism of the products is clearly shown by coercivity $\left(\mathrm{H}_{\mathrm{c}}\right)$ saturation magnetization $\left(\mathrm{M}_{\mathrm{s}}\right)$ and remnant magnetization $\left(\mathrm{M}_{\mathrm{r}}\right)$ listed in Table 2. The saturation magnetization is the maximum induced magnetic moment that can be obtained in a magnetic field, beyond

\begin{tabular}{|c|c|c|c|}
\hline Temperature $\left({ }^{\circ} \mathrm{C}\right)$ & Coercivity $\left(H_{c}\right)$ & $\begin{array}{l}\text { Magnetization } \\
\times 10^{-6} \mathrm{emu}\end{array}$ & $\begin{array}{c}\text { Retentivity } \\
\times 10^{-6}\end{array}$ \\
\hline As prepared & 1921.4 & 220.90 & 12.540 \\
\hline 200 & 2839.7 & 179.67 & 16.317 \\
\hline 400 & 1895.3 & 268.10 & 13.453 \\
\hline 600 & 4078.5 & 127.14 & 31.729 \\
\hline 800 & 3095.1 & 152.68 & 32.833 \\
\hline
\end{tabular}

Table 2: The paramagnetism of the products is clearly shown by coercivity $\left(H_{c}\right)$ saturation magnetization $\left(M_{s}\right)$ and remanent magnetization $\left(M_{r}\right)$ listed.

this field no further increase in magnetization occurs. As shown in Figure $6 \mathrm{c}$ and Table 2, the effect of $400^{\circ} \mathrm{C}$ of annealing resulted in an increase of the saturation magnetization by almost $20 \%$. Coercivity is the reverse magnetic field required to reduce the net magnetization to zero. For magnetic materials, it is necessary to reduce the coercivity as a way to control the energy losses. As shown in second column in Table 2 , as prepared and annealed at $400^{\circ} \mathrm{C} \mathrm{CdO}$ nanocrystals have relatively lower coercivity compared with that of other annealed products. Simply, remnant magnetization $\left(\mathrm{M}_{\mathrm{r}}\right)$ can be defined as the remaining magnetic momentum after realizing the magnetic field. Low remnant magnetization materials are classified as magnetically clean materials. 
Citation: Shanmugam N, Saravanan B, Reagan R, Kannadasan N, Sathishkumar K, et al. (2014) Effect of Thermal Annealing on the Cd(OH) ${ }_{2}$ and Preparation of Cdo Nanocrystals. Mod Chem appl 2: 124. doi:10.4172/2329-6798.1000124

Page 5 of 5

In some distinct fields, low remnant magnetization is highly desirable for instance in data storage applications. As shown in the last column in Table 2, both as prepared $\mathrm{Cd}(\mathrm{OH})_{2}$ and $\mathrm{CdO}$ annealed at $400^{\circ} \mathrm{C}$ have low remnant magnetization.

\section{Conclusion}

In conclusion, nanometer sized particles of $\mathrm{CdO}$ have been successfully synthesized by thermal decomposition of $\beta-\mathrm{Cd}(\mathrm{OH})_{2}$ at $400^{\circ} \mathrm{C}$. The results of XRD and FT-IR analyses confirmed the formation of CdO phase. Thermal annealing on CdO has a considerable effect of increasing the particle size. The prepared $\mathrm{CdO}$ showed visible emission at $527 \mathrm{~nm}$ that can be used in the preparation of gas sensors. FE-TEM analysis of $\mathrm{CdO}$ shows the pseudo spherical particles with diameter around $60 \mathrm{~nm}$. The $\mathrm{CdO}$ nanocrystals annealed at $400^{\circ} \mathrm{C}$ show low values of coercivity and remnant magnetization suggesting potential usage in data storage applications.

\section{References}

1. Kuo TJ, Huang MH (2006) Gold-catalyzed low-temperature growth of cadmium oxide nanowires by vapor transport. J Phys Chem B 110: 13717-13721.

2. Ferro R, Rodriguez JA (2000) Influence of F-doping on the transmittance and electron affinity of $\mathrm{CdO}$ thin films suitable for solar cells technology. Solar Energy Materials and Solar Cells 64: 363-370.

3. Guo Z, Li M, Liu J (2008) Highly porous CdO nanowires: preparation based on hydroxy- and carbonate-containing cadmium compound precursor nanowires, gas sensing and optical properties. Nanotechnology 19: 245611.

4. Li J, Ni Y, Liu J, Hong J (2009) Preparation, conversion, and comparison of the photocatalytic property of $\mathrm{Cd}(\mathrm{OH})_{2}, \mathrm{CdO}, \mathrm{CdS}$ and $\mathrm{CdSe}$. Journal of Physics and Chemistry of Solids 70: 1285-1289.

5. Liu Y, Zhang YC, Xu XF (2009) Hydrothermal synthesis and photocatalytic activity of CdO2 nanocrystals. J Hazard Mater 163: 1310-1314.

6. Lu H, Liao L, Li J, Wang D, He H, et al. (2006) High surface-to-volume ratio $\mathrm{ZnO}$ microberets: low temperature synthesis, characterization, and photoluminescence. J Phys Chem B 110: 23211-23214

7. Marinakos SM, Anderson MF, Ryan JA, Martin LD, Feldheim DL, (2001) Encapsulation, permeability, and cellular uptake characteristics of hollow nanometer-sized conductive polymer capsules. J Phys Chem B 105: 8872 8876.

8. Mondal S, Chattopadhyay T, Das S, Maulik SR, Neogi S, et al. (2012) CdO and
CdS nanoparticles from pyrolytic method: Preparation, characterization and photocatalytic activity. Indian Journal of Chemistry 51: 807-811.

9. Ortega M, Santana G, Morales-Acevedo A (2000) Optoelectronic properties of CdO/Si photodetectors. Solid-State Electronics 44: 1765.

10. Reyes MED, Delgado GT, Perez RC, Marin JM, Angel OZ (2012) Optimization of the photocatalytic activity of $\mathrm{CdO}+\mathrm{CdTiO}_{3}$ coupled oxide thin films obtained by sol-gel technique. Journal of Photochemistry and Photobiology A: Chemistry 228: 22-27.

11. Ristic M, Popovic S, Music S (2004) Formation and properties of $\mathrm{Cd}(\mathrm{OH})_{2}$ and CdO particles. Materials Letters 58: 2494-2499.

12. Abdulkarem AM, Elssfah EM, Yan NN, Demissie G, Yu Y (2013) Photocatalytic activity enhancement of CdS through in doping by simple hydrothermal method. Journal of Physics and Chemistry of Solids 74: 647-652.

13. Saravanan R, Shankar H, Prakash T, Narayanan V, Stephen A (2011) ZnO/CdO composite nanorods for photocatalytic degradation of methylene blue under visible light. Materials Chemistry and Physics 125: 277-280.

14. Saghatforoush LA, Sanati S, Mehdizadeh R, Hasanzadeh (2012) Solvothermal synthesis of $\mathrm{Cd}(\mathrm{OH})_{2}$ and $\mathrm{CdO}$ nanocrystals and application as a new electrochemical sensor for simultaneous determination of norfloxacin and lomefloxacin. Superlattices and Microstructures 52: 885-893.

15. Siraj K, Khaleeq-ur-Rahman K, Hussain SI, Rafique MS, Anjum S (2011) Effect of deposition temperature on structural , surface, optical and magnetic properties of pulsed laser deposition Al-dopped $\mathrm{CdO}$ thin films. Journal of Alloys and Compounds 509: 6756-6762.

16. Shanmugam N, Cholan S, Kannadasan N, Sathishkumar K, Viruthagiri (2014) Effect of polyvinylpyrrolidone as capping agent on $\mathrm{Ce}^{3+}$ doped flowerlike ZnS nanostructure. Solid State Sciences 28: 55-60.

17. Weckler B, Lutz HD (1996) Near-infrared spectra of $\mathrm{M}(\mathrm{OH}) \mathrm{Cl}(\mathrm{M}=\mathrm{Ca}, \mathrm{Cd}, \mathrm{Sr})$, $\mathrm{Zn}(\mathrm{OH}) \mathrm{F},-\mathrm{Cd}(\mathrm{OH})_{2}, \mathrm{Sr}(\mathrm{OH})_{2}$, and brucite-type hydroxides $\mathrm{M}(\mathrm{OH})_{2}(\mathrm{M}=\mathrm{Mg}, \mathrm{Ca}$, $\mathrm{Mn}, \mathrm{Fe}, \mathrm{Co}, \mathrm{Ni}, \mathrm{Cd})$. Spectrochimica Acta Part A: Molecular and Biomolecular Spectroscopy 52: 1507-1513.

18. Schmidt M, Lutz HD (1991) $\gamma-\mathrm{Cd}(\mathrm{OH})_{2}$, A common hydroxide or an aquoxyhydroxide? Materials Research Bulletin 26: 605-612.

19. Nakamoto K (2009) Infrared and Raman Spectra of Inorganic and Coordination Compounds, Part B, $6^{\text {th }}$ edition, John Wiley \& Sons, New Jersey, USA.

20. Johnson JC, Yan HQ, Yang PD, Saykally RJ (2003) Optical Cavity Effects in ZnO Nanowire Lasers and Waveguides. J Phys Chem B 107: 8816-8828.

21. Stichtenoth D, Ronning C, Niermann T, Wischmerier L, Voss T, et al. (2007) Optical size effects in ultrathin $\mathrm{ZnO}$ nanowires. Nanotechnology 18: 435701435705. 